\title{
Interactions between inhibin, oestradiol and progesterone in the control of gonadotrophin secretion in the ewe
}

\author{
G. B. Martin*§, C. A. Price†, J-C. Thiérył and R. Webb $\dagger$ \\ ${ }^{*} M R C$ Reproductive Biology Unit, Centre for Reproductive Biology, 37 Chalmers Street, Edinburgh \\ EH3 $9 E W, U . K . ; \dagger A F R C$ Institute of Animal Physiology \& Genetics Research, Edinburgh Research \\ Station, Roslin, Midlothian EH25 9PS, U.K. and $\ddagger I N R A$ Station de Physiologie de la \\ Reproduction, Nouzilly, 37380 Monnaie, France
}

\begin{abstract}
Summary. Experiments were carried out to test the hypothesis that inhibin and oestradiol act synergistically to inhibit the secretion of FSH, to test for effects of progesterone, and to compare the FSH and LH responses to ovarian feedback. In Exp. 1, with 11 ovariectomized and 12 intact Romanov ewes during the anoestrous season, doses of oestradiol (administered by means of subcutaneous implants) that restored normal LH pulse frequencies were insufficient to restore normal concentrations of FSH. In Exp. 2, with 48 ovariectomized Welsh Mountain ewes during the breeding season, a factorial design with 4 ewes per cell was used to assess the responses in LH and FSH to 3 doses of oestradiol (s.c. implants) and 4 doses of bovine follicular fluid ('inhibin', $0 \cdot 2-1.6 \mathrm{ml}$ s.c. every $8 \mathrm{~h}$ ). This was done initially in the absence of progesterone and then after 7 days of treatment with progesterone (s.c. implants). Analysis of variance revealed a significant synergistic interaction between oestradiol and inhibin on the plasma concentrations of FSH. Progesterone had little effect. In contrast, there was a significant synergistic interaction between oestradiol and progesterone on the concentrations of LH. 'Inhibin' also inhibited LH secretion but this effect was independent of the two steroids.

We conclude that there are basic differences in the way that ovarian feedback acts to control the secretion of $\mathrm{LH}$ and FSH in the ewe. FSH secretion appears to be primarily controlled by the synergistic action of oestradiol and inhibin on the anterior pituitary gland, while the secretion of LH is inhibited during the follicular phase by an effect of oestrogen at pituitary level and during the luteal phase by the synergistic action of oestradiol and progesterone at the hypothalamic level. Inhibin, or another non-steroidal factor in follicular fluid, may also play a minor role in the control of LH secretion.
\end{abstract}

Keywords: inhibin; oestradiol; LH; FSH; feedback; sheep

\section{Introduction}

The concentrations of FSH in peripheral plasma are maintained by a balance between the stimulatory effects of gonadotrophin-releasing hormone $(\mathrm{GnRH})$ from the hypothalamus and the inhibitory effects of feedback from the ovaries. With regard to ovarian feedback, it appears that the steroids alone are insufficient to explain the FSH patterns observed in the ewe, because manipulation of the plasma concentrations of oestradiol and progesterone with physiological doses of exogenous steroid will only partly restore the FSH patterns in ovariectomized ewes (Goodman $e t$ al., 1981), except possibly during seasonal anoestrus (Webb et al., 1985a). The missing component of the feedback loop is probably inhibin, a hormone which is thought to be secreted by the ovary and which specifically inhibits the secretion of FSH by the anterior pituitary gland (for review see 
Franchimont et al., 1979). Treatment of ewes with bovine follicular fluid (bFF), a preparation rich in inhibin, completely inhibits the rise in peripheral concentrations of FSH induced by ovariectomy (Martin et al., 1986). Inhibin therefore apparently has the potential to act alone, independently of the steroids and GnRH, and can explain any or all changes in the normal patterns of FSH secretion. However, the FSH concentrations in the ovariectomized ewes treated with bFF were significantly lower than those in intact ewes, suggesting that the dose used was outside the physiological range (Martin et al., 1986).

Assuming that steroids do play a major role, we need to establish whether they act independently of, or synergistically with, inhibin. In fact, this seems likely for the mouse, rat and mare because the intact female of these species is more sensitive to inhibin than the ovariectomized female (Marder et al., 1977; Franchimont et al., 1979; Miller et al., 1981). Progesterone may also be involved, as synergism between oestradiol and progesterone in the control of LH secretion is well documented for the ewe (review: Martin, 1984).

In the present experiments we have assessed the dose-responses to bFF (inhibin) and oestradiol in the short-term ovariectomized ewe and have tested the hypothesis that these two hormones act synergistically to inhibit the secretion of FSH. We have also tested for effects of progesterone and compared the FSH and $\mathrm{LH}$ responses in ewes in the various treatment groups.

\section{Materials and Methods}

\section{Experiment 1}

Animals. This experiment was carried out at the INRA Station de Physiologie de la Reproduction, Nouzilly, France, during the anoestrous season (mid-June). The ewes (Romanovs, 12 intact and 11 which had been ovariectomized for at least I month) had been maintained indoors in large pens since birth, under natural lighting through large windows. Blood was sampled three times weekly from the intact ewes and analysed for progesterone to verify that the animals were anovulatory (Terqui \& Thimonier, 1974).

Treatments. Eight of the ovariectomized ewes were given subcutaneous oestradiol implants 6 days before sampling. These implants were similar to those described by Goodman et al. (1981), except that they were $1 \mathrm{~cm}(4$ ewes) or $2 \mathrm{~cm}$ long (4 ewes). They were preincubated for 3 days in water at $37^{\circ} \mathrm{C}$ before implantation. Theoretically these implants release oestradiol-17 $\beta$ at the rate of about $2.3 \mu \mathrm{g} /$ day $(1 \mathrm{~cm})$ or $4.7 \mu \mathrm{g} / \mathrm{day}(2 \mathrm{~cm})$.

Blood sampling procedure. Blood was sampled every $15 \mathrm{~min}$ for $8 \mathrm{~h}$ from the ovariectomized ewes and every $20 \mathrm{~min}$ for $12 \mathrm{~h}$ from the intact ewes. The same numbers of samples were therefore taken from each ewe, although the difference in duration of sampling was intended to ensure a similar precision in the estimates of pulse frequency, which varies greatly between times and animals for intact ewes (Martin et al., 1985) but is very constant in ovariectomized ewes. Plasma was separated and stored at $-20^{\circ} \mathrm{C}$ until assayed.

Hormone assays. The assays for LH and FSH have been described in detail elsewhere (Pelletier et al., 1969; Blanc $\&$ Poirier, 1979). The samples were assayed as duplicate $100 \mu$ laliquants for $\mathrm{LH}$ and $50 \mu \mathrm{l}$ aliquants for FSH. The limits of detection were $0.06 \mathrm{ng} /$ tube (preparation M3-CNRS, activity $1.8 \mathrm{i} . \mathrm{u} . / \mathrm{mg} \mathrm{NIH-LH-S1)} \mathrm{and} 0.1 \mathrm{ng} /$ tube (preparation HG-FSH-225-226, 36 i.u./mg NIH-FSH-S3) respectively. For both gonadotrophins the within-assay coefficient of variation was $<15 \%$ and all samples from the one ewe were included in one assay to avoid the effects of inter-assay variation on the analysis of pulses.

Statistical analysis. Pulses of LH were defined as described by Martin et al. (1983). In brief: (1) both the increase and the subsequent decrease in concentration had to exceed the sum of the assay errors (coefficient of variation) appropriate for the concentrations at the onset and peak of a pulse; (2) the increase had to occupy no more than 2 sampling intervals; and (3) the decline had to begin within 2 sampling intervals of attainment of the peak. Pulse amplitude was calculated by subtracting the concentration at the onset of the pulse from the peak concentration, pulse frequency by counting the number of peaks in the sampling period, and mean concentration by averaging the concentration over the entire sampling period. There was generally more than one measure of amplitude for each profile so a mean was calculated for use in the statistical analysis. To simplify comparisons, the frequencies for the intact ewes were multiplied by 0.67 before analysis to compensate for the longer observation period. Pulses were not evident in the FSH profiles so the mean concentration for the entire profile was entered as the datum for each ewe. The effects of treatment were tested by analysis of variance and the dose-response to oestradiol by regression analysis.

\section{Experiment 2}

Animals. The experiment was carried out in the breeding season (February 1986) using 48 adult, cyclic Welsh Mountain ewes which weighed $33.6 \pm 0.6 \mathrm{~kg}$ (mean \pm s.e.m.) and were maintained at the Dryden Laboratory, 
Roslin, Midlothian, U.K. Two consecutive oestrous cycles were synchronized, the first by intravaginal sponges containing progestagen (Chronogest: Intervet, Cambridge, U.K.) and the second by a single intramuscular injection of $125 \mu \mathrm{g}$ cloprostenol (Estrumate: ICI, Cheshire, U.K.), a potent prostaglandin analogue. Oestrus was detected using a vasectomized ram.

Experimental design. A factorial design was used with 2 main treatments, bovine follicular fluid (doses: $0,0 \cdot 4,0 \cdot 8$ or $1.6 \mathrm{ml}$ ) and oestradiol (doses: 0,1 or $2 \mathrm{~cm}$ s.c. implants). Each cell of the design contained 4 ewes allocated at random. The ewes in all of the treatment groups were also treated with progesterone for 7 days, beginning about 8 days after ovariectomy, allowing the use of a split-plot design for analysis of the effects of progesterone and its interactions with the other treatments.

Treatments. The ewes were ovariectomized, between Days 13 and 15 of the oestrous cycle, at mid-ventral laparotomy under general anaesthesia induced by $12 \mathrm{ml} 5 \%(\mathrm{w} / \mathrm{v})$ thiopentone sodium (May \& Baker Ltd, Dagenham, U.K.) and maintained with $2 \%$ halothane in oxygen. The subcutaneous oestradiol implants were inserted while the animals were still under anaesthesia. The peripheral concentrations provided by the implants were $3 \cdot 3 \pm 0 \cdot 2$ and $4.9 \pm 0.3 \mathrm{pg} / \mathrm{ml}$, for the $1 \mathrm{~cm}$ and $2 \mathrm{~cm}$ implants respectively. These values compare with $2.0 \pm 0.9 \mathrm{pg} / \mathrm{ml}$ in the control ewes $(0 \mathrm{~cm})$. Progesterone was also administered with 2 s.c. implants (Silestrus, Cevar Ltd, Southampton, U.K.), which provided peripheral plasma concentrations of $5.2 \pm 0.3 \mathrm{ng} / \mathrm{ml}$. Before implantation, the concentration of progesterone was $0.29 \pm 0.02 \mathrm{ng} / \mathrm{ml}$.

Fluid (bFF) was aspirated from the large, non-cystic follicles in cow ovaries obtained from a local abattoir. After centrifugation ( $1500 \mathrm{~g}$ for $30 \mathrm{~min}$ at $4^{\circ} \mathrm{C}$ ) the fluid was pooled so that the experiment could be completed with a single batch and then it was extracted with charcoal, a treatment which removes about $98 \%$ of the steroids (Wallace $\&$ McNeilly, 1985). The bFF was stored in small aliquants at $-20^{\circ} \mathrm{C}$ until it was required. It was injected subcutaneously every $8 \mathrm{~h}(08: 00,16: 00$ and $24: 00 \mathrm{~h})$ from 16:00 h on the day of ovariectomy until the end of the experiment.

Throughout the experimental period, blood was sampled by jugular venepuncture from control and treated ewes just before the injections at 08:00 h. Samples were also taken every $3 \mathrm{~h}$ for $27 \mathrm{~h}$ about 8 days after ovariectomy, just before the administration of progesterone, and 7 days later, just before the progesterone implants were removed. Plasma was separated and stored at $-20^{\circ} \mathrm{C}$ until it was assayed for LH, FSH, progesterone and oestradiol- $17 \beta$.

Hormone assays. The assays for LH and FSH have been described in detail elsewhere (McNeilly, J.R. et al., 1976; McNeilly, A.S. et al., 1986). The samples were assayed as duplicate $100 \mu \mathrm{l}$ aliquants for $\mathrm{LH}$ and $150 \mu \mathrm{l}$ aliquants for FSH. Antisera R3(1-1) and M94 were used for the LH and FSH assays and the limits of detection were $0.04 \mathrm{ng}$ NIHLH-S23/tube and $0.6 \mathrm{ng}$ NIH-FSH-S14/tube respectively. Assay variation was estimated using pooled plasma samples containing a range of hormone concentrations which were assayed in at least 5 replicates in each assay. For both gonadotrophins the within-assay coefficient of variation was $<15 \%$ and all samples from one ewe were assayed in the same run to avoid the effects of inter-assay variation on the analysis of the response to progesterone.

Progesterone concentrations were measured in extracts of $150 \mu$ l aliquants of plasma using the assay described by Djahanbahkch et al. (198I). The intra-assay coefficient of variation was $11.6 \%$ and the detection limit was $0 \cdot 2 \mathrm{ng} / \mathrm{ml}$. All samples were included in one assay. The oestradiol in 3-ml samples of plasma was extracted by affinity chromatography and assayed as previously described (Webb et al., 1985b). To provide the large volume of plasma, samples from within each of the 27 -h sampling periods were pooled. The concentration of oestradiol did not differ significantly between the sampling periods. All samples were measured in a single assay, in which the limit of detection was $0.97 \mathrm{pg} /$ tube, the extraction efficiency was $77 \%$, the water blanks were below the limit of detection, and the intra-assay coefficient of variation was $7 \cdot 8 \%$.

The inhibin bioactivity in bFF was estimated in 2 bioassays based on the inhibition of FSH release by sheep and rat pituitary cells in vitro (Tsonis et al., 1986). The inhibin reference standard was ovine rete testis fluid (oRTF) with an arbitrary potency of 1 unit/mg (Eddie $e t$ al., 1979), similar to the preparation OTLP-6 used by Findlay $e t$ al. (1985). The mean inhibin potency of the bFF preparation used in the current experiment was $4.46 \mathrm{ku} / \mathrm{ml}(95 \%$ confidence limits $3 \cdot 14-6 \cdot 19 \mathrm{ku})$ in the rat cell assay and $13.35 \mathrm{ku} / \mathrm{ml}(11 \cdot 38-15 \cdot 67 \mathrm{ku} / \mathrm{ml})$ in the sheep cell assay. The index of precision was $<20 \%$ for both bioassays.

Statistical analysis. Changes in hormone concentration with time were subjected to analysis of variance for factorial and split-plot design after logarithmic transformation of the data. All the data for each gonadotrophin were analysed as a single model. The effects of treatments on the gonadectomy response were only tested statistically for the period beginning 3 days after ovariectomy when the responses were essentially completed and the concentrations of both gonadotrophins had reached a plateau.

\section{Results}

\section{Experiment 1}

The amplitude of the LH pulses was not significantly affected by ovariectomy or oestrogen treatment (Fig. 1). Both sizes of implant reduced pulse frequency in the ovariectomized ewes $(P<0.01)$ and the responses to the 2 doses differed in that 3 of the 4 ewes in the group treated with 2 -cm implants had no LH pulses in the observation period whereas the ewes in the $1-\mathrm{cm}$ group had 

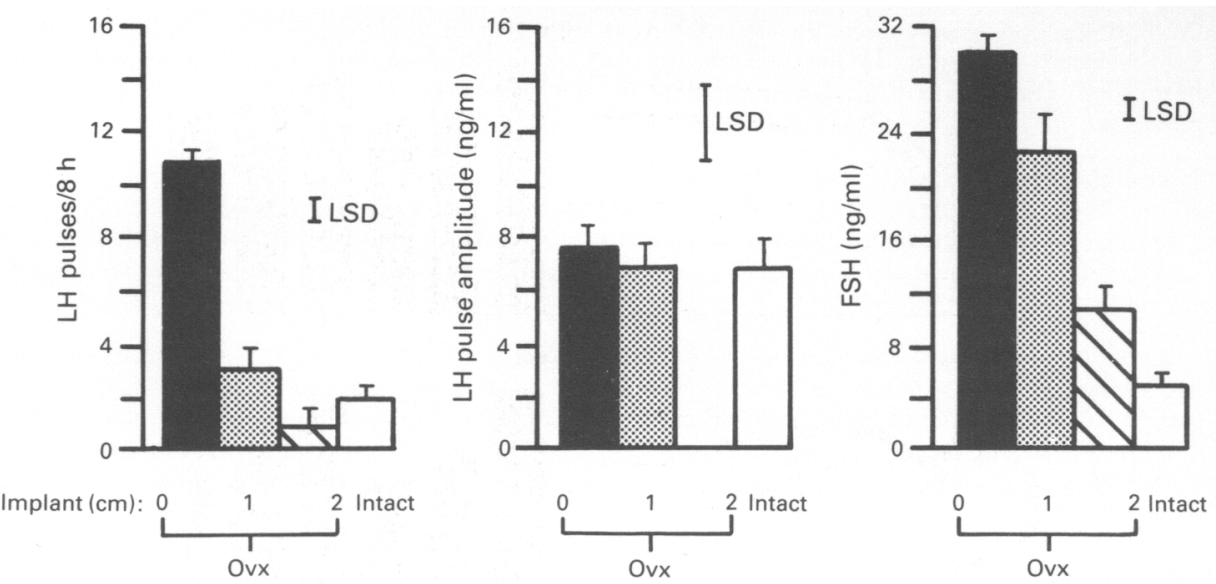

Fig. 1. Comparison of the secretion of LH and FSH in intact $(N=12)$ and ovariectomized (Ovx, $\mathrm{N}=11$ ) ewes. The ovariectomized ewes were untreated $(0 \mathrm{~cm}, \mathrm{~N}=3)$ or given s.c. oestradiol implants which were $1 \mathrm{~cm}(\mathrm{~N}=4$ ewes $)$ or $2 \mathrm{~cm}(\mathrm{~N}=4)$ long. LSD = least significant difference. Insufficient $\mathrm{LH}$ pulses were observed in the $2 \mathrm{~cm}$ group for accurate measurement of pulse amplitude. The dose-responses for length of implant against pulse frequency $(r=0.92)$ and mean FSH concentration $(r=0.90)$ were both significant $(P<0.001)$.

1-4 pulses. The frequencies in both groups were similar to those in the intact ewes, among which only 1 animal had no pulses in $12 \mathrm{~h}$. Within the ovariectomized ewes, pulse frequency was linearly related to dose of oestradiol $(\mathrm{R}=0.85, P<0.001)$.

The mean concentrations of FSH were also reduced by both sizes of oestrogen implant $(P<0.001)$ and again the effect was dose-dependent $(\mathrm{R}=0.81, P<0.001)$. However, in contrast with the effects of the implants on $\mathrm{LH}$ pulse frequency, neither dose was sufficient to restore FSH concentrations to the range $(8 \cdot 3-15 \cdot 0 \mathrm{ng} / \mathrm{ml})$ observed in the intact ewes. The concentrations in the $2-\mathrm{cm}$ group were still about double those in the intact group.

\section{Experiment 2}

Plasma FSH concentrations. After ovariectomy, the concentrations of FSH in the control ewes increased and, in the absence of bFF, oestradiol clearly reduced the concentrations in a doseresponsive manner (Fig. 2, histograms). This effect of oestradiol was also evident in ewes treated with the two lowest doses of bFF, but not in the ewes treated with the highest dose, in which the plasma FSH concentrations fell to undetectable levels in most ewes about 5 days after ovariectomy (Fig. 2). The concentration of FSH was maintained at a value similar to that before ovariectomy in only 3 groups of ewes, namely those treated with $0.4 \mathrm{ml}$ bFF and $1-$ or 2-cm oestradiol implants, and those treated with $0.8 \mathrm{ml} \mathrm{bFF}$ and a $1-\mathrm{cm}$ implant. Analysis of variance showed that there were significant $(P<0.001)$ main effects of bFF and oestradiol and that the interaction between these treatments was also significant $(P<0 \cdot 01)$. This interaction is demonstrated in the histograms showing the dose-responses in Fig. 2, especially when the effects of dose of oestradiol at the lowest two doses of bFF are compared with the effects in ewes not given bFF. No main effect of progesterone was evident in the plasma FSH concentrations (Fig. 2) or in the analysis of variance, but the interaction between oestradiol and progesterone was significant $(P<0.05)$ because FSH concentrations were lower before than after progesterone implantation in ewes not treated with oestradiol $(1.50$ vs $1.66 \log \mathrm{ng} / \mathrm{ml}$, s.e.d. $=0.05)$, but not affected by progesterone in ewes treated with small $(1.17$ vs $1.19 \log \mathrm{ng} / \mathrm{ml})$ or large $(0.85$ vs $0.79 \mathrm{log} \mathrm{ng} / \mathrm{ml})$ oestradiol implants. The interaction between $\mathrm{bFF}$ and progesterone was not statistically significant.

Plasma LH concentrations. Ovariectomy also induced an increase in plasma LH concentrations which was inhibited by oestradiol in a dose-dependent manner and, in the absence of bFF, the $2-\mathrm{cm}$ 


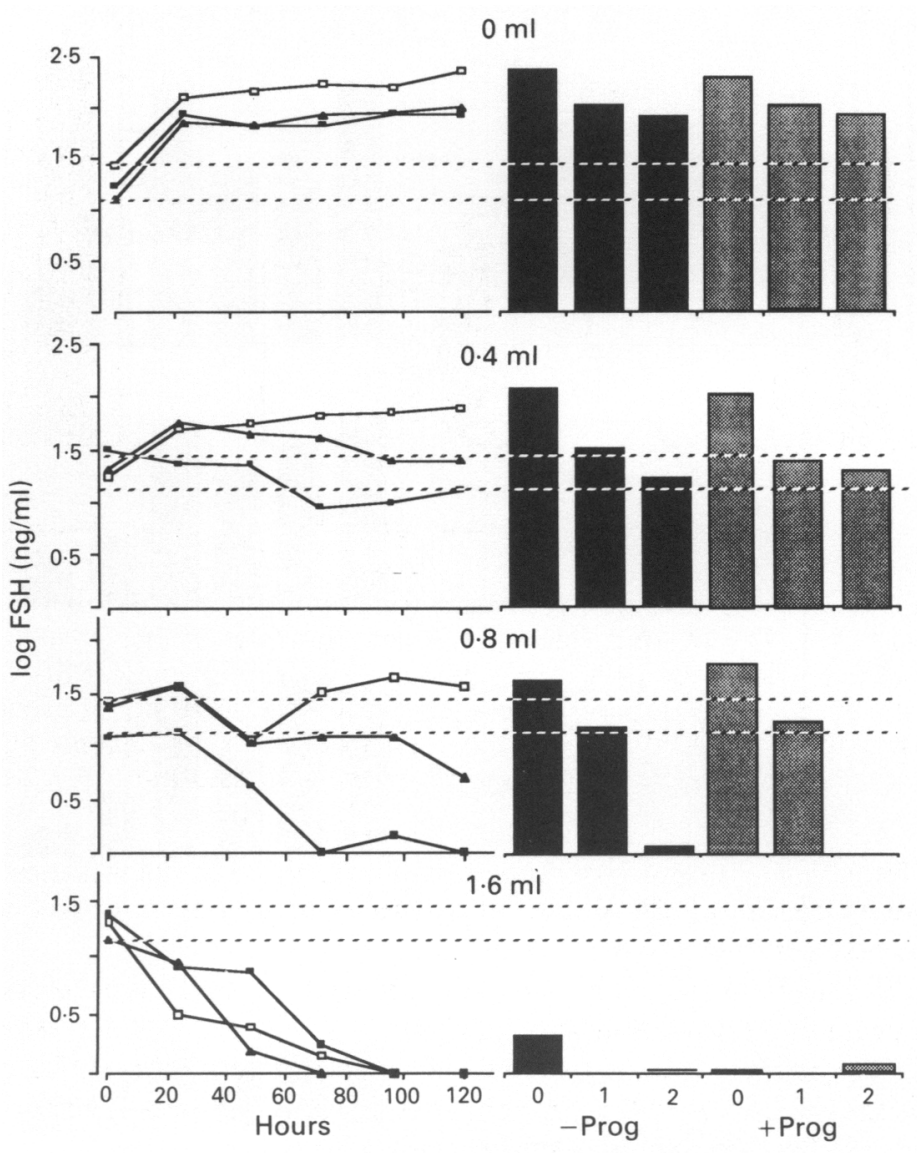

Fig. 2. Effect of inhibin, oestradiol and progesterone on the secretion of FSH in acutely ovariectomized ewes (Exp. 2). Left panels: changes in plasma FSH concentrations after ovariectomy $($ at $0 \mathrm{~h}$ ) in control ewes $(0 \mathrm{ml})$ and ewes treated with $0.4 \mathrm{ml}, 0.8 \mathrm{ml}$ or $1.6 \mathrm{ml} \mathrm{bFF}$ every $8 \mathrm{~h}$. The ewes were also treated with oestradiol implants which were $0 \mathrm{~cm}(\square-\square), 1 \mathrm{~cm}(\boldsymbol{\Lambda}-\boldsymbol{\Lambda})$ or $2 \mathrm{~cm}$ (-D) long. There were 4 ewes in each treatment group of the factorial design. Right panels: responses to oestradiol and bFF as measured in samples taken every $3 \mathrm{~h}$ for $27 \mathrm{~h}$ before the addition of progesterone (-Prog., black histograms) and after treatment with progesterone (+Prog., stippled histograms). The doses of oestradiol $(0,1$ or $2 \mathrm{~cm}$ implant length) are indicated at the foot of the figure. Note the logarithmic scales for FSH concentration. The broken lines indicate the mean \pm 1 s.d. of the concentration before ovariectomy $(N=48)$.

oestradiol implant was able to maintain the values within the range observed before ovariectomy (Fig. 3). In the absence of oestradiol, treatment with bFF also reduced the response to ovariectomy in a dose-dependent manner (histograms, Fig. 3). If the oestradiol treatments were pooled, the concentrations of $\mathrm{LH}$ were $0.65,0.45,0.42$, and $0.30 \mathrm{log} \mathrm{ng} / \mathrm{ml}$ for doses of $0,0.4,0.8$ and $1.6 \mathrm{ml}$ bFF respectively (s.e.d. $=0.067 \mathrm{log} \mathrm{ng} / \mathrm{ml}, P<0.001$ ). The interactions of bFF with oestradiol and progesterone were not statistically significant. The imposition of progesterone had no effect on ewes not treated with oestradiol, but led to a sharp decline in plasma LH concentrations in all the groups treated with oestradiol, as demonstrated by a steepening of the slopes of the oestradiol dose-responses (histograms, Fig. 3). Analysis of variance revealed this interaction to be significant $(P<0.001)$. 


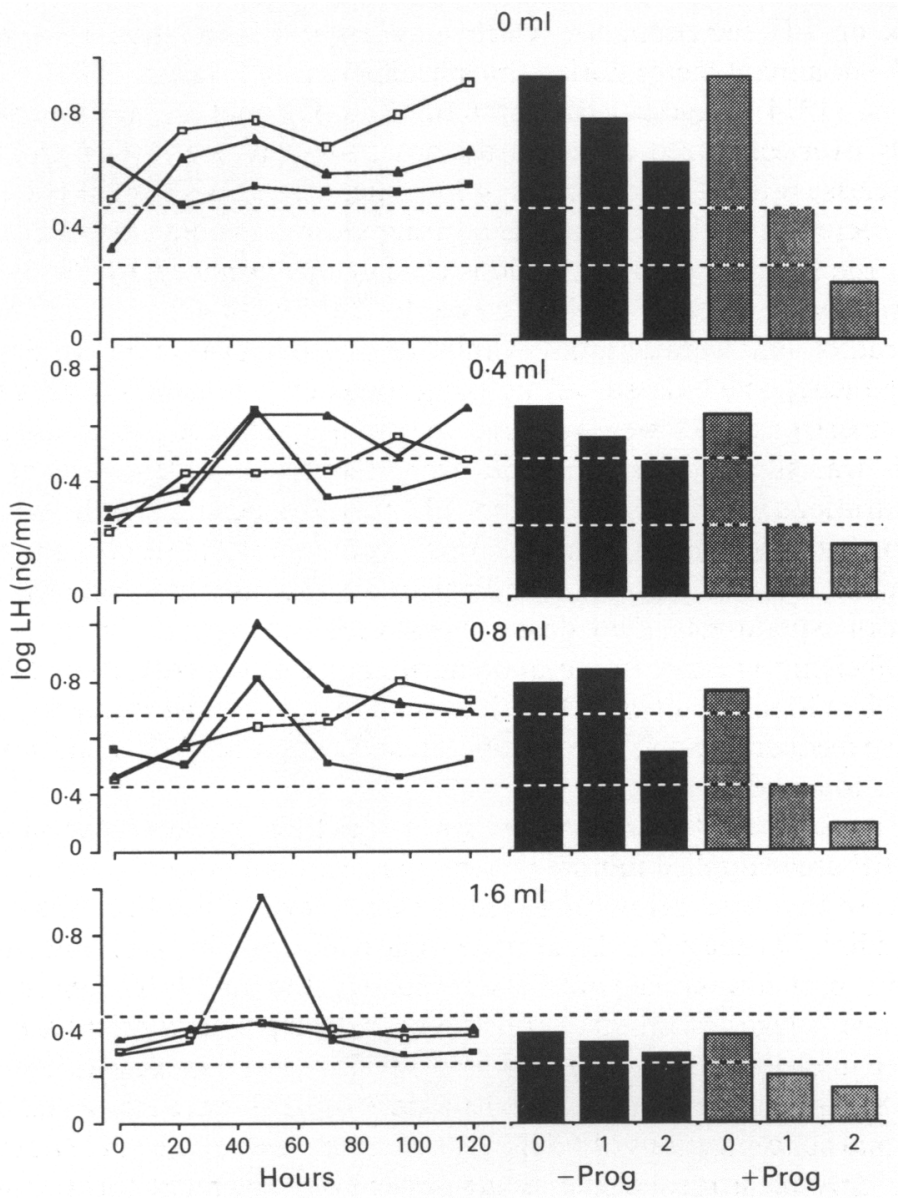

Fig. 3. Effect of inhibin, oestradiol and progesterone on the secretion of LH in acutely ovariectomized ewes (Exp. 2). Left panels: changes in plasma LH concentrations after ovariectomy (at $0 \mathrm{~h}$ ) in control ewes $(0 \mathrm{ml})$ and ewes treated with $0.4 \mathrm{ml}, 0.8 \mathrm{ml}$ or $1.6 \mathrm{ml} b F F$ every $8 \mathrm{~h}$. The ewes were also treated with oestradiol implants which were $0 \mathrm{~cm}(\square-\square), 1 \mathrm{~cm}(\boldsymbol{\Delta}-\boldsymbol{\Delta})$ or $2 \mathrm{~cm}$ (口- ) long. There were 4 ewes in each treatment group of the factorial design. Right panels: responses to oestradiol and bFF as measured in samples taken every $3 \mathrm{~h}$ for $27 \mathrm{~h}$ before the addition of progesterone (-Prog., black histograms) and after treatment with progesterone ( + Prog., stippled histograms). The doses of oestradiol $(0,1$ or $2 \mathrm{~cm}$ implant length) are indicated at the foot of the figure. Note the logarithmic scales for LH concentration. The broken lines indicate the mean \pm 1 s.d. of the concentration before ovariectomy $(\mathrm{N}=48)$.

\section{Discussion}

In this study we have shown that FSH secretion is inhibited by a synergistic interaction between two ovarian hormones, oestradiol and inhibin. When administered simultaneously to ovariectomized ewes, in doses which probably correspond to normal ovarian output, oestradiol and inhibin were able to maintain plasma concentrations of FSH within the range observed in intact ewes. When the two hormones were given independently, the same doses were relatively ineffective. The other important ovarian product, progesterone, does not appear to play a major role in the control of FSH release. The control of FSH secretion by inhibin and oestradiol contrasts with 
ovarian feedback on LH secretion, for which a synergistic interaction between oestradiol and progesterone is the dominant factor during the breeding season (Martin, 1984).

Cumming et al. (1974) suggested that oestradiol alone could maintain normal FSH concentrations in acutely ovariectomized ewes, but the doses they infused ( $1 \mu \mathrm{g} / \mathrm{h}$ i.v.) were significantly greater than the release rates of our implants $(0 \cdot 1-0 \cdot 2 \mu \mathrm{g} / \mathrm{h}$ s.c.). Similarly, Webb et al. (1985a) have shown that FSH secretion could be controlled during seasonal anoestrus with oestradiol implants alone but, again, the peripheral concentrations $(5-6 \mathrm{pg} / \mathrm{ml})$ provided by the 3-cm implants were double those normally observed in the intact ewe. In the present experiments, on the other hand, the doses of oestradiol used were certainly within the physiological range. In Exp. 1 we effectively used LH pulse frequency as a bioassay of the exogenous oestradiol and the data show that normal frequencies for anoestrous ewes were restored by the oestradiol implants used, particularly the smaller one. This was supported by the data from Exp. 2, in which we were able to measure oestradiol concentrations in the plasma (but not LH pulse frequency) and the same sizes of implant were found to provide peripheral concentrations comparable to those normally seen during anoestrus and the luteal (1-cm implant) or follicular $(2-\mathrm{cm})$ phases in intact ewes (Goodman et al., 1981, 1982). In both experiments, these doses of oestradiol strongly inhibited the secretion of FSH but were never sufficient to restore or maintain normal plasma concentrations. We therefore agree with the proposal by Goodman et al. (1981) that other factors are necessary for the full expression of ovarian negative feedback on this gonadotrophin and data from the second study presented here suggest that factor to be inhibin.

We cannot be as definite with regard to the doses of inhibin, however, except to suggest that the highest dose of bFF used supplied inhibin at a greater rate than normal ovarian output, because it reduced FSH release to a level below that seen in intact ewes. This effect was exacerbated by the addition of oestradiol. On the other hand, when injected into ewes carrying small (luteal phase) oestradiol implants, both lower doses of bFF were sufficient to hold FSH concentrations within the normal intact range, suggesting that ovarian output during the luteal phase is approximately equivalent to three injections of about $0.6 \mathrm{ml} \mathrm{bFF}$ per day. This agrees with our previous findings (Martin et al., 1987). Although there must exist a dose of bFF (between $0.8 \mathrm{ml}$ and $1.6 \mathrm{ml}$ ) which will maintain normal concentrations of FSH in the ovariectomized ewe in the absence of oestradiol, this possibility is only of academic interest as oestradiol is secreted throughout the luteal and follicular phases of the oestrous cycle and also throughout the anoestrous season (Baird \& Scaramuzzi, 1976; Scaramuzzi \& Baird, 1977; Baird, 1978).

The effects of oestradiol and inhibin on FSH release are most likely to be exerted on the anterior pituitary gland. There is little evidence to suggest that inhibin alters the release of GnRH (review: Franchimont et al., 1979) and it has been established for the ewe that inhibin reduces pituitary responsiveness to GnRH, reduces pituitary FSH content and inhibits GnRH-independent FSH secretion (Martin et al., 1986) but has little effect on LH pulse frequency, a variable solely under hypothalamic control (Martin et al., 1987). The effect of the highest dose of bFF on mean LH concentrations in Exp. 2 is probably due to a reduction in pulse amplitude (Martin et al., 1987). Similarly, in the ewe during the breeding season, oestradiol does not affect LH (or GnRH) pulse frequency unless progesterone is also present (Goodman et al., 1982; Martin et al., 1983) yet has been shown to reduce pulse amplitude by reducing the response to GnRH (Goodman \& Karsch, 1980), so it also acts at the pituitary rather than the hypothalamic level. If GnRH secretion is affected by oestradiol or inhibin, alone or in combination, it will be expressed in terms of GnRH pulse amplitude, a possibility which remains to be tested.

The effect of the interaction between oestradiol and progesterone on FSH concentrations also requires some comment. Oestradiol and progesterone act synergistically to reduce the frequency of GnRH pulses released by the hypothalamus (review: Martin, 1984), and the interactive effect of these two steroids on the mean concentrations of LH in the present study is presumably a reflection of this action. The secretion of FSH is also controlled by GnRH pulse frequency (Clarke $e t$ al., 1984) and, since there was no major effect of progesterone in the absence of oestradiol on the 
release of FSH or LH in the current experiment, and no interaction with bFF, it seems most likely that the interaction with oestradiol was exerted at the hypothalamic level.

The question remains as to whether progesterone plays an important role in the regulation of FSH secretion. During the luteal phase, when the activity of the hypothalamo-hypophysial system is dominated by the inhibitory effects of oestradiol and progesterone on GnRH pulse frequency, it is possible that FSH secretion would be held in check by both the low GnRH pulse frequency and by the effects of inhibin and oestradiol on pituitary responsiveness. These two effects would probably be additive. However, the contribution of the hypothalamic component seems to be relatively unimportant because, in contrast to the dramatic increase in LH secretion when progesterone concentrations fall after luteolysis, there is a decrease in the secretion of FSH (Wallace et al., 1987). Furthermore, in the present study, the concentrations of FSH were not affected by progesterone in ewes given luteal-phase concentrations of oestradiol (1-cm implant) and were only reduced by progesterone in the ewes treated with follicular phase concentrations of oestradiol, yet the plasma concentrations of progesterone are very low during the follicular phase. Overall, then, it seems unlikely that this steroid plays a major role in the regulation of FSH secretion under normal conditions. One possible exception might be an abnormal circumstance which allowed a high concentration of oestradiol during the luteal phase.

In our previous study, we found that bFF would partly inhibit the increase in mean LH concentrations which is induced by ovariectomy (Martin et al., 1986). Findlay et al. (1985) observed a comparable effect of ovine follicular fluid in long-term ovariectomized ewes. We suggested that this was due to the high dose of inhibin used in these studies $(2.5 \mathrm{ml}$ bFF every $8 \mathrm{~h}$ by Martin et al., 1986) and that more physiological doses of inhibin would prove specific for FSH release. This was supported by the results of a recent experiment in which we took blood samples every $10 \mathrm{~min}$ and found that LH pulse amplitude was reduced only by large doses of bFF (Martin et al., 1987). In the present study, the lowest doses of inhibin reduced the mean concentrations of $\mathrm{LH}$, but gonadotrophin secretion was assessed in 3-h samples, a regimen which may be adequate for FSH but is obviously inadequate for a hormone such as LH, which is released in pulses. Nevertheless, as we have argued above, these doses appear to be similar to the rate of secretion by the ovaries, so we should accept the possibility that inhibin, or some other factor in follicular fluid, plays a role in the regulation of $\mathrm{LH}$ secretion. The physiological importance of this factor requires further investigation, but is probably minor because (1) there was no interaction with oestradiol or progesterone, (2) neither of the lower doses of bFF could hold LH concentrations within the intact range, and (3) the effects observed were small compared to those exerted by the steroids.

To summarize, we have demonstrated basic differences in the way that ovarian feedback controls the secretion of LH and FSH in the ewe. During the anoestrous season and follicular phase of the oestrous cycle, FSH secretion is primarily controlled by the synergistic action on the anterior pituitary gland of oestradiol and inhibin from the ovarian follicles. In contrast, the secretion of $\mathrm{LH}$ is inhibited during anoestrus by oestradiol alone, through an effect on the frequency of the GnRH pulses secreted by the hypothalamus, and during the follicular phase by an effect at pituitary level on LH pulse amplitude (review: Martin, 1984). During the luteal phase, oestradiol and inhibin still exert the main regulatory influence over FSH secretion, and progesterone may have a modulatory influence through the effect it has on GnRH pulse frequency. Again, this is fundamentally different from the feedback on LH secretion, which is controlled by the synergistic action of oestradiol and progesterone on the hypothalamic pulse generator. Inhibin or some other nonsteroidal factor synthesized by the follicles may play a minor role in the control of LH pulse amplitude.

We thank Dr A. S. McNeilly for helpful comments on the experimental design; A. Springbett for help with the statistical analysis; N. Anderson for care of the animals; Dr C. Fabre-Nys, Y. Cognié and Dr G. W. Montogmery for help with the sampling; and Dr J. Pelletier, Dr M. Blanc, J-C. Poirier, Dr P. L. Taylor, G. Baxter and D. McBride for help with the assays. While in 
France, G.B.M. was supported by an Overseas Study Award from the Australian Meat Research Committee.

\section{References}

Baird, D.T. (1978) Pulsatile secretion of LH and ovarian estradiol during the follicular phase of the sheep estrous cycle. Biol. Reprod. 18, 359-364.

Baird, D.T. \& Scaramuzzi, R.J. (1976) Changes in the secretion of ovarian steroids and pituitary luteinizing hormone in the peri-ovulatory period in the ewe: effect of progesterone. J. Endocr. 70, 237-245.

Blanc, M. \& Poirier, J-C. (1979) A new homologous radioimmunoassay for ovine follicle-stimulating hormone: development and characterization. Annls Biol. anim. Biochim. Biophys. 19, 1011-1026.

Clarke, I.J., Cummins, J.M., Findlay, J.K., Burman, K.J. \& Doughton, B.W. (1984) Effects on plasma luteinizing hormone and follicle-stimulating hormone of varying the frequency and amplitude of gonadotropin-releasing hormone rulses in ovariectomized ewes with hypothalamo-pituitary disconnection. Neuroendocrinology 39, 214-221.

Cumming, I.A., Baxter, R.W., Buckmaster, J.M., Jonas, H.A., Findlay, J.K. \& Goding, J.R. (1974) Control of FSH secretion in the ewe. J. Reprod. Fert. 36, $447-448$

Djahanbahkch, O., Swanston, I.A., Corrie, J.E.T. \& McNeilly, A.S. (1981) Prediction of ovulation by progesterone. Lancet 8256, 1164-1165.

Eddie, L.W., Baker, H.W.G., Higginson, R.E. \& Hudson, B. (1979) A bioassay for inhibin using pituitary cells in culture. $J$. Endocr. 81, 49-60.

Findlay, J.K., Gill, T.W. \& Doughton, B.W. (1985) Influence of season and sex on the inhibitory effect of ovine follicular fluid on plasma gonadotrophins in gonadectomized sheep. J. Reprod. Fert. 73, 329-335.

Franchimont, P., Verstraelen-Proyard, J., HazeeHagelstein, M.T., Renard, C., Demoulin, A., Bourguignon, J.P. \& Hustin, J. (1979) Inhibin: from concept to reality. Vitams Horm. 37, 243-302.

Goodman, R.L. \& Karsch, F.J. (1980) Ovarian feedback control of luteinizing hormone in the ewe: evidence for selective suppression. Endocrinology 107, $1286-1290$.

Goodman, R.L., Pickover, S.M. \& Karsch, F.J. (1981) Ovarian feedback control of follicle-stimulating hormone in the ewe: evidence for selective suppression. Endocrinology 108, 772-777.

Goodman, R.L., Bittman, E.L., Foster, D.L. \& Karsch, F.J. (1982) Alterations in the control of luteinizing hormone pulse frequency underlie the seasonal variation in estradiol negative feedback in the ewe. Biol. Reprod. 27, 580-589.

Marder, M.L., Channing, C.P. \& Schwartz, N.B. (1977) Suppression of serum follicle-stimulating hormone in intact and acutely ovariectomized rats by porcine follicular fluid. Endocrinology 101, 1639-1642.

Martin, G.B. (1984) Factors affecting the secretion of luteinizing hormone releasing hormone in the ewe. Biol. Rev. 59, 1-87.
Martin, G.B., Scaramuzzi, R.J. \& Henstridge, J. (1983) Effects of oestradiol, progesterone and androstenedione on the pulsatile secretion of luteinizing hormone in ovariectomized ewes during spring and autumn. J. Endocr. 96, 181-193.

Martin, G.B., Cognié, Y., Schirar, A., Nunes-Ribeiro, A., Fabre-Nys, C. \& Thiéry, J-C. (1985) Diurnal variation in the response of anoestrous ewes to the ram effect. J. Reprod. Fert. 75, 275-284.

Martin, G.B., Wallace, J.M., Taylor, P.L., Fraser, H.M., Tsonis, C.G. \& McNeilly, A.S. (1986) The roles of inhibin and gonadotrophin-releasing hormone in the control of gonadotrophin secretion in the ewe. $J$. Endocr. 111, 287-296.

Martin, G.B., Taylor, P.L. \& McNeilly, A.S. (1987) Effect of small doses of bovine follicular fluid on the tonic secretion of gonadotrophins in the ewe. $J$. Endocr. 114, 73-79.

McNeilly, A.S., Jonassen, J.A. \& Fraser, H.M. (1986) Suppression of follicular development after chronic LHRH immunoneutralization in the ewe. $J$. Reprod. Fert. 76, 481-490.

McNeilly, J.R., MeNeilly, A.S., Walton, J.S. \& Cunningham, F.J. (1976) Development and application of a heterologous radioimmunoassay for ovine follicle-stimulating hormone. J. Endocr. 70, 69-79.

Miller, K.F., Wesson, J.A. \& Ginther, O.J. (1981) Interaction of estradiol and a nonsteroidal follicular fluid substance in the regulation of gonadotropin secretion in the mare. Biol. Reprod. 24, 354-358.

Pelletier, J., Kann, J., Dolais, J. \& Rosselin, G. (1969) Dosage radioimmunologique de l'hormone luteinisante plasmatique chez le mouton. Mise au point de la technique de dosage. C. r. hebd. Séanc. Acad. Sci. Paris D 226, 2291-2294.

Scaramuzzi, R.J. \& Baird, D.T. (1977) Pulsatile release of luteinizing hormone and the secretion of ovarian steroids in sheep during anestrus. Endocrinology 101, 1801-1806.

Terqui, M. \& Thimonier, J. (1974) Nouvelle methode radioimmunologique rapide pour l'estimation du niveau de progestérone plasmatique. Application pour le diagnostic précoce de la gestation chez la brebis et la chèvre. C. r. hebd. Séanc. Acad. Sci. Paris D 279, $1109-1112$.

Tsonis, C.G., McNeilly, A.S. \& Baird, D.T. (1986) The measurement of exogenous and endogenous inhibin in sheep serum using a new and extremely sensitive bioassay for inhibin based on ovine pituitary FSH secretion in vivo. J. Endocr. 110, 341-352.

Wallace, J.M. \& McNeilly, A.S. (1985) Increase in ovulation rate after treatment of ewes with bovine follicular fluid in the luteal phase of the oestrous cycle. $J$. Reprod. Fert. 73, 505-515.

Wallace, J.M., Martin, G.B. \& McNeilly, A.S. (1987) Changes in the secretion of LH pulses, FSH and prolactin during the preovulatory phase of the oestrous 
cycle of the ewe and the influence of previous treatment with bovine follicular fluid during the luteal phase. J. Endocr. (in press).

Webb, R., Baxter, G., Preece, R.D., Land, R.B. \& Springbett, A.J. (1985a) Control of gonadotrophin release in Scottish Blackface and Finnish Landrace ewes during seasonal anoestrus. J. Reprod. Fert. 73, $369-378$.
Webb, R., Baxter, G., McBride, D., Nordblum, G.D. \& Shaw, M.P.K. (1985b) The measurement of testosterone and oestradiol-17 $\beta$ using iodinated tracers and incorporating an affinity chromatography extraction procedure. J. Steroid Biochem. 23, 1043-1051.

Received 16 June 1987 